\title{
ASSESSMENT OF PAVLIK HARNESS EFFECTIVENESS IN 3-6 MONTHS OLD PATIENTS WITH UNSTABLE HIPS
}

\author{
INSTABIL KALÇAYA SAHIP, 3-6 AYLIK HASTALARIN TEDAVISINDE PAVLIK BANDAJI \\ ETKINLIĞININ DEĞERLENDIRILMESI
}

\author{
Tuna PEHLivANOĞLU1,2 (D), Serkan BAYRAM ${ }^{3}$ (D), Mehmet DEMIREL ${ }^{3}$ (D), Mustafa Abdullah ÖZDEMiR ${ }^{3}$ (D) \\ Yavuz SAĞLAM ${ }^{3}$ (D), Turgut AKGÜL ${ }^{3}$ (D) Fuat BiLGiLi ${ }^{3}$ (D) \\ 'Emsey Hospital, Department of Orthopaedics and Traumatology, Istanbul, Turkey \\ ${ }^{2}$ Yeni Yüzyıl University, Faculty of Health Sciences, Istanbul, Turkey \\ ${ }^{3}$ Istanbul University, Istanbul Faculty of Medicine, Department of Orthopaedics and Traumatology, Istanbul, Turkey
}

ORCID IDs of the authors: T.P. 0000-0001-8886-7538; S.B. 0000-0001-7651-1200; M.D. 0000-0003-1131-7719;

M.A.Ö. 0000-0002-8281-3528; Y.S. 0000-0003-4475-8211; T.A. 0000-0002-0704-3797; F.B. 0000-0002-9417-2166

Cite this article as: Pehlivanoglu T, Bayram S, Demirel M, Ozdemir MA, Saglam Y, Akgul T, et al. Assessment of the effectiveness of pavlik harness in management of unstable hip patients between the age of three and six months. J Ist Faculty Med 2021;84(3):342-7. doi: 10.26650/IUITFD.2021.879703

\section{ABSTRACT}

Objective: To investigate the effectiveness of the Pavlik harness $(\mathrm{PH})$ in the treatment of patients who were diagnosed with unstable hips aged between three and six months.

Material and Method: We retrospectively reviewed patients aged three to six months who were diagnosed with unstable hips and treated with the $\mathrm{PH}$. The patients were treated using $\mathrm{PH}$ and were closely followed by a weekly clinical examination. The primary outcome was to assess the success rate of $\mathrm{PH}$ treatment in children with unstable hips (Graf Type IID, III, IV). A successful outcome as a result of $\mathrm{PH}$ treatment was defined as either obtaining a Type I hip based on Graf's method of hip ultrasonography or a concentric reduction based on hip radiography.

Results: Thirty-three patients' 34 hips were included in this study with a diagnosis of DDH based on hip sonography performed according to the Graf's method at the time of initial admission to our department. The mean age of the children in the beginning of the PH treatment was 17 weeks (range, 14-22); the mean follow-up was 48 months (range, 24-84). On admission, the mean alpha angle was 46 (range, 35-58). According to the Graf classification, DDH was determined as Type D in 18 hips (52\%), Type IIla in 5 hips, Type IIIB in 3 (24\%) and Type IV in 8 (24\%). Of these 34 hips, 28 (82\%) were treated successfully using $\mathrm{PH}$, with a mean application time of 11.24 weeks (range, 4-20). The success rate of $\mathrm{PH}$ treatment was determined as $82 \%$ (28/34 hips).

Conclusions: Favorable outcomes can be expected from $\mathrm{PH}$

\section{ÖZET}

Amaç: Üç ila altı aylık stabil olmayan kalça teşhisi konulan hastaların tedavisinde pavlik bandajın (PB) etkinliğinin araştııılması.

Gereç ve Yöntem: Üç ila altı aylık stabil olmayan kalça teşhisi konulan ve pavlik bandajı ile tedavi edilen hastalar geriye dönük olarak incelendi. Hastaların stabil olmayan kalçaları PB kullanılarak tedavi edildi ve haftalık olarak klinik muayene ile yakından takip edildi. Birincil sonuç kriteri, stabil olmayan kalçaları olan çocuklarda PB tedavisinin başarı oranını değerlendirmekti (Graf'a göre tip IID, III, IV). Başarı kriterleri, Graf'ın kalça ultrasonografisi yöntemine göre tip I kalça veya kalça radyografisinde konsantrik redüksiyon elde edilmesi olarak tanımlandı.

Bulgular: Bölümümüze ilk başvuru sırasında Graf yöntemine göre ultrasonografik muayene ile tanı konan 33 hasta ve 34 kalça çalışmaya dahil edildi. Pavlik bandajı tedavisinin başlangıcında çocukların ortalama yaşı 17 hafta (aralık, 14-22); ortalama takip süresi 48 ay (aralık, 24-84) olarak saptandı. Başvuru anında ortalama alfa açısı 46 (aralık, 35-58) olarak ölçüldü. Graf sınıflandırmasına göre GKD, 18 kalça Tip D (\%52), 5 kalçada Tip IIla, 3 (\%24) tip IIIB ve 8 (\%24) tip IV olarak saptandı. Bu 34 kalçadan 28'i (\%82), ortalama 11,24 hafta (aralık, 4-20) uygulama süresi ile PB kullanılarak başarıyla tedavi edildi. $\mathrm{PH}$ tedavisinin başarı oranı \%82 (28/34 kalça) olarak belirlendi.

Sonuç: Instabil kalçası olan (Graf Tip IID, III, IV) üç ila altı ay arasında tanı konulan hastalarda PB tedavisinden başarılı sonuçlar elde edilebilir.

Corresponding author/iletişim kurulacak yazar: dr.serkanbayram89@gmail.com

Submitted/Başvuru: 24.02.2021 • Revision Requested/Revizyon Talebi: 07.04.2021 •

Last Revision Received/Son Revizyon: 14.04.2021 • Accepted/Kabul: 14.04.2021 • Published Online/Online Yayın: 13.07.2021 
treatment in patients with unstable hips (Graf Type IID, III, IV) who are diagnosed between the age of three and six months.

Keywords: Developmental dysplasia of the hip; Pavlik harness; harness treatment; treatment success rate; late-diagnosed hip dysplasia
Anahtar Kelimeler: Gelişimsel kalça displazisi; Pavlik bandajı; bandaj tedavisi; tedavi başarı oranı; geç teşhis edilen gelişimsel kalça displazisi

\section{INTRODUCTION}

Today, after more than 50 years, the Pavlik harness (PH) treatment, which works physiologically based on the principle that 'the hip is an organ of movement and must be treated by movement', has been the method of choice to manage children with developmental dysplasia of the hip $(\mathrm{DDH})(1,2)$. The PH treatment remains the mostly preferred treatment modality, especially in patients younger than six months of age, because $\mathrm{PH}$ is the most thoroughly analyzed type of splint and reported to be safe and highly effective method as compared to any other type of splint in large series of patients (3-6). Nonetheless, there is disagreement in the literature about the optimal age to begin $\mathrm{PH}$ treatment. Most authors advocate that the harness can endow successful results as long as the treatment is initiated before the age of two to three months (4-8).

Conversely, some authors suggest that there is no correlation between age at the start of treatment and failure of PH treatment $(9,10)$. According to our review of the literature, there certainly needs to be more research to clarify the question about whether the $\mathrm{PH}$ is a safe and effective method of treatment for patients with unstable hips diagnosed after three months of age. However, $\mathrm{PH}$ treatment is not effective after six months of age $(4,9)$.

Therefore, the present study aimed to investigate the effectiveness of the PH in the treatment of a specific group of children who were diagnosed with unstable hips aged between three and six months.

\section{MATERIAL AND METHOD}

\section{Study design}

We retrospectively reviewed 87 patients (127 hips) who were treated with the $\mathrm{PH}$ after suffering from $\mathrm{DDH}$ with a subluxated or dislocated hip from 2009 to 2016 in a single center (university hospital). According to the eligibility criteria as shown in Table 1, after 54 children (93 hips) were excluded, the remaining 33 children (34 hips) with an unstable hip ( 25 females and 8 males) who were diagnosed between the ages of three to six months and treated using $\mathrm{PH}$ were included in the present study. This retrospective study was approved by the Institutional Review Board; written and informed consent was obtained from the patients' parents.

After detailed clinical examination, all of these 33 patients underwent hip sonography based on Graf's method at the time of initial admission to our department. The mean age of the children in the beginning of the $\mathrm{PH}$ treatment was 17 weeks (range, 14-22); the mean follow-up was 48 months (range, 24-84) (Table 2). On admission, the mean alpha angle was 46 (range, 35-58).

Table 2: Demographic characteristics of the study participants

\begin{tabular}{ll}
\hline $\begin{array}{l}\text { Mean age at the start of } \mathrm{PH}^{*} \\
\text { treatment (week) }\end{array}$ & 17 (range, 14-22) \\
Gender & 25 females, 8 males \\
Side, R/L & $21 / 13$ \\
Bilateral involvement & 1 \\
Unilateral involvement & 32 \\
Follow-up duration (month) & 48 (range, 24-84) \\
\hline
\end{tabular}

*PH: Pavlik harness

\section{Management protocol and primary outcome parameters} The patients' unstable hips were treated using the $\mathrm{PH}$ and closely followed by weekly clinical examination. The $\mathrm{PH}$ was applied by a single pediatric orthopedic surgeon

Table 1: Eligibility criteria for inclusion and exclusion of the study participants

\section{Inclusion criteria}

A diagnosis of typical $\mathrm{DDH}^{*}$

Children with unstable hips (Type IID, III, IV**) who were diagnosed after 3 months of age

Being willing to participate the study

\author{
Exclusion criteria \\ $<3$ months old at the time of diagnosis \\ $<2$ years of follow-up \\ Lost to follow-up \\ Concomitant neuromuscular comorbidities \\ Teratological dislocations \\ Previous failed orthosis treatment \\ Unwilling to participate the study
}

*DDH: Developmental dysplasia of the hip, **The diagnosis of DDH was established based on the Graf's method of hip ultrasonography 
for all patients, and the parents were advised regarding the proper use of the $\mathrm{PH}$. Concentric reduction of unstable hips was assessed using ultrasonography with a three-week-interval. All patients were also evaluated with a hip radiograph to assess the ossific nucleus of the femoral head and hip morphology. Additionally, patients who developed the ossific nucleus of the femoral head were also evaluated radiologically to assess the reduction after applying the $\mathrm{PH}$.

Establishing success as a result of $\mathrm{PH}$ treatment in three to six month old children, who were diagnosed with unstable hips after performing a sonography according to Graf's method (Type IID, III, IV) was the main goal of the present study. Success was defined as achieving either a Type I hip after performing a hip sonography according to Grafs method or detection of a concentric reduction on hip X-ray.

The application of the PH continued until a stable hip was obtained or concentric reduction was determined by plain radiography. If stable reduction was obtained, but residual acetabular dysplasia was noticed on the final radiograph, the bandage was switched to a custom-made abduction splint for two or three months. If no reduction on plain radiography or no Graf-type improvement was observed within three weeks of $\mathrm{PH}$ treatment, the treatment was considered to have failed. The treatment was subsequently discontinued, and closed reduction combined with the application of a hip-spica cast was performed. As soon as use of the harness was ceased, a standard anteroposterior radiograph of the hip was taken to evaluate the reduction of the femoral head and acetabular development. The patients were then regularly monitored by radiographic examination at one year of age and then once annually.

Radiographic examination (anteroposterior and frog leg lateral X-rays) was performed after the cessation of the treatment with $\mathrm{PH}$, at the end of the treatment with hip abduction orthosis, and at the final follow-up visit. In order to assess residual acetabular dysplasia, the acetabular index (AI) as described by Hilgenreiner was measured on all AP radiographs (11). The Kalamchi and MacEwen classification were also used to examine avascular necrosis of the femoral head (AVN) (12). In an effort to minimize observer and measurement bias, all radiographic assessments were carried out by a single pediatric orthopedic surgeon.

\section{RESULTS}

According to Graf classification, DDH was determined as Type D in 18 hips (52\%), Type IIla in 5 hips, Type IIIb in 3 (24\%) and Type IV in 8 (24\%). Of these 34 hips, 28 (82\%) had been treated successfully with $\mathrm{PH}$, with a mean application time of 11.24 weeks (range: $4-20$ ). The mean time from the beginning of treatment to stable reduction was 11 weeks (range: 4-20). Since a stable hip according to hip sonography or a concentric reduction on hip radiography was not obtained as a result of $\mathrm{PH}$ treatment in six unstable hips (3 with Type IIIB, 3 with Type IV) of five children; they were treated with closed reduction and a hip-spica cast, which was performed under general anesthesia. When these results were taken into account, the success rate of $\mathrm{PH}$ treatment was determined as $82 \%$ (28/34 hips) (Table 3).

Table 3: Rates of successful treatment

\begin{tabular}{|c|c|}
\hline $\mathrm{DDH}^{*}$ type ${ }^{* *}$ & Success rate \\
\hline Type D & 17/18 (95\%) \\
\hline Type IIla & $3 / 5(60 \%)$ \\
\hline Type IIIb & $2 / 3(66 \%)$ \\
\hline Type IV & 6/8 (75\%) \\
\hline
\end{tabular}

${ }^{*} \mathrm{DDH}$ : Developmental dysplasia of the hip

**DDH was categorized according to Graf classification

During the follow-up period, four unstable hips (four children) were treated successfully with the $\mathrm{PH}$. However, the ultrasonographic examination could not be performed due to the development of the femoral head ossification center. In these hips, PH treatment was ceased when the stable and concentric reduction was determined based on plain radiography and physical examination. In the remaining 24 unstable hips of 24 patients, the mean alpha angle improved from $46^{\circ}$ (range, $35^{\circ}-58^{\circ}$ ) on admission to $62^{\circ}$ (range, $60^{\circ}-65^{\circ}$ ) at the end of the $\mathrm{PH}$ treatment.

The average Al of children treated successfully with the $\mathrm{PH}$ significantly improved from $34.5^{\circ}$ (range: $30^{\circ}-38.5^{\circ}$ ) after $\mathrm{PH}$ treatment to $18.2^{\circ}$ (range: $14^{\circ}-22^{\circ}$ ) at a mean follow-up of 48 months (range: $24-84$ months). According to Tönnis's criteria regarding the DDH in pediatric population, only one child had a mild dysplasia (13). Furthermore, the final radiographic examination revealed that two hips of patients (1 with type IIIB and 1 with Type IV), in whom PH failed and closed reduction and a hip-spica cast was performed, had developed AVN according to the Kalamchi and MacEwen classification (1 hip with Type I, 1 hip with Type IV). Otherwise, the children treated successfully by PH showed no signs of AVN. Additionally, no other complications including femoral nerve palsy or skin breakdown occurred during the follow-up.

\section{DISCUSSION}

Many authors have referred to the $\mathrm{PH}$ as the first-choice of treatment in children younger than months of age due to its dynamic role in terms of hip reduction $(2,14-16)$. Nonetheless, the literature lacks consensus regarding the optimal age to begin $\mathrm{PH}$ treatment. Although most 
authors have proposed that substantially higher success rates can be expected if the treatment is initiated prior to the age of two to three months (4-8), some studies have suggested that the age at the start of treatment was not an indicator of success for PH treatment $(9,10)$. Besides, most studies regarding this topic have included a heterogeneous group of patients in terms of hip stability (Graf type), and a limited number of studies in the literature have specifically focused on the success rate of $\mathrm{PH}$ in unstable hips (Type D-III-IV as per Graf classification) after three months of infancy $(1,4-9)$.

Unlike most studies on the topic, we more specifically asked if the $\mathrm{PH}$ is a safe and effective nonsurgical treatment for children with unstable hips diagnosed after three months of infancy. Therefore, our study specifically focused on a certain group of patients with severe problems and reflected the results of $\mathrm{PH}$ treatment for these unstable hips. The evidence from the present study demonstrated that the $\mathrm{PH}$ may be an influential technique in achieving stable reduction with a low rate of complications for children with unstable hips (Graf Type IID, III, IV) who are diagnosed with DDH and treated between three and six months of age.

Lerman et al. assessed predictors of treatment failure for $\mathrm{PH}$ in 93 patients (137 hips) with DDH (9). Seventeen patients (26 hips) failed the $\mathrm{PH}$ treatment, and the authors found no correlation between initiation of treatment and rates of failure. However, in the failed group, only two patients were aged three months or older. Therefore, their results could not be extrapolated to the whole late-diagnosed DDH. In contrast, in a study which included 31 cases of DDH of Graf Type Ilc or more severe cases, Atalar et al. found Graf type, age at start of treatment, and bilaterality as the success indicators of $\mathrm{PH}$ treatment (4). In their study, the mean age at the start of treatment was eight weeks, with age ranging from 4 to 20 weeks In this study, children aged seven weeks and under exhibited a higher rate of success than those aged eight weeks and over. Furthermore, patients with Type IIc, D or III hips presented a higher rate of treatment success than patients with Type IV hips, and patients with bilateral DDH had a lower rate of treatment success than patients with unilateral involvement (4). They emphasized that the beginning of $\mathrm{PH}$ treatment before the $7^{\text {th }}$ week of infancy was the key aspect for successful outcomes in the management of DDH. Similar$l y$, in another study which analyzed the factors affecting the success rate of this treatment modality in 153 children $(\leq 6$ months of age) with DDH treated using the $\mathrm{PH}$, Ömeroğlu et al. found the treatment starting age as the only patient-related variable (5). In their study, although more than $90 \%$ of patients under three months of age (37 of 40 ) were treated successfully, the treatment failed in one-third of patients older than five months of age (9 of 24). Additionally, Ömeroğlu et al. stated that both a lower initial alpha an- gle and a higher Graf hip type decreased the success rate of $\mathrm{PH}$ treatment, since unsuccessful results were obtained in more than two-thirds of Graf Type III hips and two of four Graf Type IV hips (5). Therefore, they concluded that the threshold values for increased risk of treatment failure with $\mathrm{PH}$ were an age older than four months and an alpha angle less than $46^{\circ}$. Lastly, in a more recent study in this topic, Larson et al. reported a study which included 176 children with 38 patients (21.6\%) failing $\mathrm{PH}$ treatment (17). In that study, patients were divided based on the age at which the $\mathrm{PH}$ was initiated (group $1 \leq 30$ days, group $2=30$ to 60 days, group $3 \geq 60$ days). They concluded that there was no difference in the failure rates by age.

AVN, the most catastrophic complication of DDH treatment, still poses a complicated diagnostic and treatment challenge for orthopedic surgeons. What is more, because of the complex and multifactorial etiology, the development of this devastating complication remains difficult to predict (18). Although the rate of AVN following successful reduction is reported to be low, ranging from $0 \%$ to $22 \%$, higher rates of AVN are attributed to fixed dislocation, unsuccessful reduction, bilateral hip involvement as well as presentation beyond three months of age $(9,18-20)$. In a retrospective study which set out to analyze 100 children with distinct levels of hip instability treated using $\mathrm{PH}$, Kokavec et al. drew the conclusion that Pavlik's method is safe and accurate for all dysplastic and subluxated hips, together with the great majority of dislocated hips (1). However, the authors emphasized that late onset and prolonged duration of the $\mathrm{PH}$ treatment were associated with higher rates of treatment failure and AVN. In our study, we observed no evidence of AVN in children with unstable hips treated successfully by $\mathrm{PH}$; however, AVN occurred in two hips (1 hip with Type I, 1 hip with Type IV) in whom closed reduction using a hip spica cast was applied because of failure of $\mathrm{PH}$. Therefore, we believe that the major predictive factor for AVN in the treatment of DDH may be the failure of $\mathrm{PH}$ as well as the severity of the pathology. Nonetheless, although the present study displayed satisfactory outcomes of PH treatment, the likelihood of complications including AVN and late acetabular dysplasia may compromise the results at the long term follow-up $(10,21,22)$.

Residual acetabular dysplasia has been implicated as one of the most prevalent complications following the treatment of DDH (23). In our series, at the end of a median follow-up duration of four years, no residual acetabular dysplasia was observed based on radiographic measurements except for one child who had a mild acetabular dysplasia. However, Fujika et al. reported a severe dysplasia rate of $19 \%$ in a series of 380 patients with a follow-up duration of more than 20 years (21). Similarly, Tucci et al. warned against late acetabular dysplasia in patients with hip instability treated with $\mathrm{PH}$ and suggested that all such patients should be monitored until skeletal maturity (22). 
Therefore, patients in the present study seem to need further follow-up evaluations in order not to miss probable residual dysplasia.

In a comparative study, Westacott et al. found no significant difference with regard to results or complications between staged and immediate cessation after successful treatment using PH (3). In our study, the treatment was stopped as soon as a stable hip was obtained according to ultrasonographic examination, or concentric reduction was observed on plain radiography. We observed no recurrence or reintervention after immediate cessation in our case series. However, based on the present study, due to the lack of a control group, whether or not immediate cessation was superior to staged cessation could not be determined.

This study has several important limitations. The first limitation was the retrospective nature of the study. Second, the follow-up period in this study was limited to the middle-term outcomes. Third, this study did not include a control group. Lastly, the Barlow and Ortoloni examinations in the initial evaluation of these patients were not included.

\section{CONCLUSION}

With successful outcomes and low morbidity, favorable outcomes can be expected from PH treatment for children with unstable hips (Graf Type IID, III, IV) who are diagnosed between the age of three and six months. Otherwise, there certainly needs to be much more research to clarify the safety and effectiveness of the $\mathrm{PH}$ for this particular group of patients.

Peer Review: Externally peer-reviewed.

Author Contributions: Conception/Design of Study- T.P., S.B., M.A.Ö., M.D.; Data Acquisition- S.B., T.P., Y.S., F.B.; Data Analysis/Interpretation- T.A., T.P., S.B., M.D.; Drafting Manuscript- T.P., S.B., M.D., M.A.Ö.; Critical Revision of Manuscript- Y.S., T.A., F.B.; Final Approval and Accountability- T.P., S.B., M.D., M.A.Ö., Y.S., T.A., F.B.

Conflict of Interest: Authors declared no conflict of interest.

Financial Disclosure: Authors declared no financial support.

\section{Hakem Değerlendirmesi: Dış bağımsız.}

Yazar Katkıları: Çalışma Konsepti/Tasarım- T.P., S.B., M.A.Ö., M.D.; Veri Toplama- S.B., T.P., Y.S., F.B.; Veri Analizi/YorumlamaT.A., T.P., S.B., M.D.; Yazı Taslağı- T.P., S.B., M.D., M.A.Ö.; İçeriğin Eleştirel Incelemesi- Y.S., T.A., F.B.; Son Onay ve Sorumluluk- T.P., S.B., M.D., M.A.Ö., Y.S., T.A., F.B.

Çıkar Çatışması: Yazarlar çıkar çatışması beyan etmemişlerdir.

Finansal Destek: Yazarlar finansal destek beyan etmemişlerdir.

\section{REFERENCES}

1. Kokavec M, Makai F, Olos M, Bialik V. Pavlik's method: a retrospective study. Arch Orthop Trauma Surg 2006;126(2):73-6. [CrossRef]

2. Pollet V, Pruijs H, Sakkers R, Castelein R. Results of Pavlik harness treatment in children with dislocated hips between the age of six and twenty-four months. J Pediatr Orthop 2010;30(5):437-42. [CrossRef]

3. Westacott DJ, Mackay ND, Waton A, Webb MS, Henman $\mathrm{P}$, Cooke SJ. Staged weaning versus immediate cessation of Pavlik harness treatment for developmental dysplasia of the hip. J Pediatr Orthop B 2014;23(2):103-6. [CrossRef]

4. Atalar H, Sayli U, Yavuz OY, Uraş I, Dogruel H. Indicators of successful use of the Pavlik harness in infants with developmental dysplasia of the hip. Int Orthop 2007;31(2):145-50. [CrossRef]

5. Omeroglu H, Kose N, Akceylan A. Success of Pavlik Harness Treatment Decreases in Patients > 4 Months and in Ultrasonographically Dislocated Hips in Developmental Dysplasia of the Hip. Clin Orthop Relat Res 2016;474(5):114652. [CrossRef]

6. Cashman J, Round J, Taylor G, Clarke N. The natural history of developmental dysplasia of the hip after early supervised treatment in the Pavlik harness. J Bone Joint Surg $\mathrm{Br}$ 2002;84(3):418-25. [CrossRef]

7. Harding MG, Harcke HT, Bowen JR, Guille JT, Glutting J. Management of dislocated hips with Pavlik harness treatment and ultrasound monitoring. J Pediatr Orthop 1997;17(2):189-98. [CrossRef]

8. Viere R, Birch J, Herring J, Roach J, Johnston C. Use of the Pavlik harness in congenital dislocation of the hip. An analysis of failures of treatment. J Bone Joint Surg Am 1990;72(2):238-44. [CrossRef]

9. Lerman JA, Emans JB, Millis MB, Share J, Zurakowski D, Kasser JR. Early failure of Pavlik harness treatment for developmental hip dysplasia: clinical and ultrasound predictors. J Pediatr Orthop 2001;21(3):348-53. [CrossRef]

10. Uçar DH, Isklar ZU, Kandemir U, Tümer Y. Treatment of developmental dysplasia of the hip with Pavlik harness: prospective study in Graf type Ilc or more severe hips. J Pediatr Orthop B 2004;13(2):70-4. [CrossRef]

11. Thieme WT, Thiersch JB. Translation: Hilgenreiner on congenital hip dislocation. J Pediatr Orthop 1986;6(2):20214. [CrossRef]

12. Kalamchi A, MacEwen GD. Avascular necrosis following treatment of congenital dislocation of the hip. J Bone Joint Surg Am 1980;62(6):876-88. [CrossRef]

13. Tönnis $D$. Normal values of the hip joint for the evaluation of X-rays in children and adults. Clin Orthop Relat Res 1976;119:39-47. [CrossRef]

14. Westacott DJ, Mackay ND, Waton A, Webb MS, Henman P, Cooke SJ. Staged weaning versus immediate cessation of Pavlik harness treatment for developmental dysplasia of the hip. J Pediatr Orthop B 2014;23(2):103-6. [CrossRef]

15. Nakamura J, Kamegaya M, Saisu T, Someya M, Koizumi W, Moriya H. Treatment for developmental dysplasia of the hip using the Pavlik harness. J Bone Joint Surg Br 2007;89(2):230-5. [CrossRef] 
16. Ramsey P, Lasser S, MacEwen G. Congenital dislocation of the hip. Use of the Pavlik harness in the child during the first six months of life. J Bone Joint Surg Am 1976;58(7):1000-4. [CrossRef]

17. Larson JE, Patel AR, Weatherford B, Janicki JA. Timing of Pavlik Harness Initiation: Can We Wait? J Pediatr Orthop 2019;39(7):335-8. [CrossRef]

18. Tiruveedhula M, Reading IC, Clarke NM. Failed Pavlik harness treatment for DDH as a risk factor for avascular necrosis. J Pediatr Orthop 2015;35(2):140-3. [CrossRef]

19. Kitoh $H$, Kawasumi $M$, Ishiguro $N$. Predictive factors for unsuccessful treatment of developmental dysplasia of the hip by the Pavlik harness. J Pediatr Orthop 2009;29(6):552-7. [CrossRef]
20. Suzuki SG, Yamamuro T. Avascular necrosis in patients treated with the Pavlik harness for congenital dislocation of the hip. J Bone Joint Surg Am 1990;72(7):1048-55. [CrossRef]

21. Fujioka F, Terayama K, Sugimoto N, Tanikawa H. Longterm results of congenital dislocation of the hip treated with the Pavlik harness. J Pediatr Orthop 1995;15(6):747-52. [CrossRef]

22. Tucci JJ, Kumar SJ, Guille JT, Rubbo ER. Late acetabular dysplasia following early successful Pavlik harness treatment of congenital dislocation of the hip. J Pediatr Orthop 1991;3(4):502-5. [CrossRef]

23. Carsi B, Al-Hallao S, Wahed K, Page J, Clarke NM. Incomplete periacetabular acetabuloplasty. Acta Orthop 2014;85(1):66-70. [CrossRef] 